\title{
Rainfall Infiltration Into and Seepage From Rock Dumps — A Review
}

\author{
D.J. Williams The University of Queensland, Australia
}

T.K. Rohde The University of Queensland, Australia

\begin{abstract}
Mine rock typically emerges from an open pit relatively dry, and is conventionally stored in surface dumps where it progressively becomes wet-up by rainfall infiltration over time. Slow infiltration into the rock dump following light rainfall is likely to be largely restricted to the traffic-compacted surficial layer of the dump from which much of it is likely to be evaporated. Rapid infiltration into the rock dump following prolonged heavy rainfall is likely to be dominated by flow along distinct preferred seepage pathways, leading to deep drainage and the emergence of some of this as seepage from the base of the dump. Rainfall infiltration into a bare, loosely-dumped rock dump is commonly assumed to be 30 to $60 \%$ of average annual rainfall, depending on the climate, and the physical and chemical characteristics of the rock. However, there is a lack of field data to confirm this. A $15 \mathrm{~m}$ high trial rock dump covering 0.71 ha was constructed at a mine in New South Wales, Australia. It was instrumented with two lysimeters at the surface of the dump and 24 lysimeters at the base of the dump to monitor infiltration through the top and base seepage beneath the top surface and the side slopes of the dump. The paper presents the results of 16 months of monitoring of the trial rock dump lysimeters. They show that total infiltration into the top of the trial dump was about $50 \%$ of the total 16months of well below average rainfall, with the majority of the infiltration going into storage within the dump and only a minor amount reaching the base of the dump via preferred seepage pathways. Runoff from the top of the trial dump is not allowed so that the remaining $50 \%$ of the total rainfall was lost to evaporation from surface ponding. The trigger rainfall required for base seepage was found to reduce exponentially from about $30 \mathrm{~mm}$ initially to $2.5 \mathrm{~mm}$, and the response time from about 10 days to 2.5 days as the dump wets-up. A review of the literature and other sources is also presented that provides available data worldwide on rainfall infiltration into and seepage from rock dumps located in a range of climates.
\end{abstract}

\section{Introduction}

Understanding how rainfall infiltrates, is stored within and is transported through a rock dump is essential to predicting the release to the environment of mineral weathering products from the dump. Rates of water flow through a rock dump are not well understood, being a function of the climate, the method of dump construction and resulting dump structure, and the physical and chemical characteristics of the rock.

\subsection{Conventional surface rock dump construction}

Before discussing the mechanisms of rainfall infiltration into surface rock dumps, it is necessary to examine their structure. Surface rock dumps are conventionally constructed by loose end-dumping from haul trucks off a series of tip-heads forming a number of lifts, with benches between lifts to allow haul truck movements. From each tip-head, the rock ravels down-slope at the angle of repose of the material (35 to $40^{\circ}$ to the horizontal, the angle being least for high slopes of weathered rock and greatest for fresh rock). Since the larger boulders (typically up to $1 \mathrm{~m}$ in size) ravel to the toe of the slope, a rubble zone is formed at the base of each lift, which ensures the ready ingress of oxygen (Herasymuik et al., 1995). The bulk of the slope will comprise discontinuous, alternating layers, typically 0.3 to $1 \mathrm{~m}$ thick, of fine and coarse-grained rock due to the pattern of ravelling caused by the discrete truck dumping operations. The flat tops of each of the lifts, being heavily trafficked by haul trucks and dozers, will comprise compacted, fine-grained material, typically finer than $100 \mathrm{~mm}$ in size, having a thickness of the order of $1 \mathrm{~m}$. The compacted surfaces will be capable of allowing rainfall runoff to pond temporarily, before it is lost to infiltration and evaporation.

The structure of a conventional surface rock dump renders it an oxidation reactor with respect to any reactive materials present. Oxygen will readily enter the dump through the base rubble zone, from which it migrates up the coarse-grained angle of repose layers, before diffusing into the adjacent fine-grained angle of repose 
layers. The fine-grained material presents the highest surface area per unit volume and hence is the most potentially reactive. Oxygen can also enter the dump via its loose side slopes, with limited diffusion of oxygen through the traffic-compacted top of the dump. Any movement of water through the dump will pick up any oxidation products and potentially deliver them to the environment, either by seepage to the foundation or from the toe of the dump along buried surface drainage channels.

\subsection{Rainfall infiltration and seepage mechanisms}

The water balance of a surface rock dump includes rainfall infiltration, runoff (if this is allowed) and evaporation (both from surface ponding and from storage in near surface layers). The mechanisms of rainfall infiltration include preferred pathway flow and the progressive more broad-scale wetting up of the dump. Initially, any base seepage will occur via preferred pathway flow along open "pipes" within the dump, triggered by heavy rainfall events or the cumulative storage of rainfall infiltration within the dump over time. During the early life of a surface rock dump, while base seepage may be relatively high at the localised "pipes", the total amount of seepage over the area of the dump is likely to be small.

Cumulative rainfall infiltration will cause a wetting up of a surface rock dump over time, at a rate dependent largely upon the climate. The net infiltration will largely be retained in storage, particularly within the finegrained angle of repose layers within the dump. Eventually, depending upon the climate and the nature of the rock, an uncovered dump will wet up sufficiently that there are continuous water pathways through the dump and any rainfall infiltration will be matched by base seepage, resulting in "continuum breakthrough" and a far greater potential for contaminant transport to the environment.

\section{Cadia's trial rock dump}

A $15 \mathrm{~m}$ high trial rock dump covering 0.71 ha was constructed at Cadia Hill Gold mine in New South Wales, Australia. It was instrumented with two surface lysimeters at its traffic-compacted top to monitor rainfall infiltration, and 24 lysimeters at its base to monitor base seepage beneath the flat, traffic-compacted top surface (14 lysimeters) and the loose, angle of repose side slopes (10 lysimeters) of the dump. A plan showing the layout of the trial rock dump and the locations of the surface lysimeters and the base lysimeters (numbered 1 to 24) is shown in Figure 1. The trial covers shown in Figure 1 are not discussed in this paper. In addition to the lysimeters, a purpose-built weather station measuring rainfall, air temperature, relative humidity, solar radiation, and wind speed and wind direction was installed on the top of the trial rock dump.

The sloping site for the trial rock dump was built up using 540,000 t of non-acid forming (NAF) rock to form a 1.56 ha base platform, and the trial dump itself was constructed of 110,000 t of NAF rock (at each end) and $90,000 \mathrm{t}$ of potentially acid forming (PAF) rock in between. The base area of the trial rock dump is 0.71 ha and the top area of the dump is 0.21 ha, of which 0.12 ha is PAF rock. The NAF base platform was constructed by end-dumping from haul trucks between October and December 2005, and the trial rock dump itself was constructed between December 2005 and January 2006.

Heavy rainfall occurred during the construction of the trial rock dump resulting in an average volumetric moisture content for the placed rock of about 0.11 (gravimetric moisture content of $6.2 \%$, for a measured specific gravity of 2.65), saturating about a third of the porosity of about 0.33 (corresponding to an initial dry density of $1.78 \mathrm{t} / \mathrm{m}^{3}$ ).

\subsection{Lysimeter design, construction and monitoring}

\subsubsection{Lysimeter design principles}

Lysimeters under non-atmospheric (that is, buried) conditions may create an elevated water boundary condition at the base of the lysimeter and therefore the hydraulic gradient within the lysimeter is different to that surrounding the lysimeter (Bews et al., 1997; O'Kane and Barbour, 2003). To ensure that this difference does not cause "wicking" of water from the wetter lysimeter backfill to the drier surrounding material, the lysimeter wall height must exceed the height of capillary rise above any elevated water boundary condition within the lysimeter. 
For the backfill and surrounding materials available for the Cadia trial rock dump base lysimeters, the configuration required to prevent wicking was a minimum wall height of $0.1 \mathrm{~m}$. A wall height of $1 \mathrm{~m}$ was selected, providing a very large factor of safety against wicking. For the surface lysimeters, atmospheric conditions apply and the wall height required is a function of constructability and the need for the lysimeter backfill to replicate the undisturbed state. A wall height of $2.3 \mathrm{~m}$ (the highest available) was selected for the surface lysimeters.

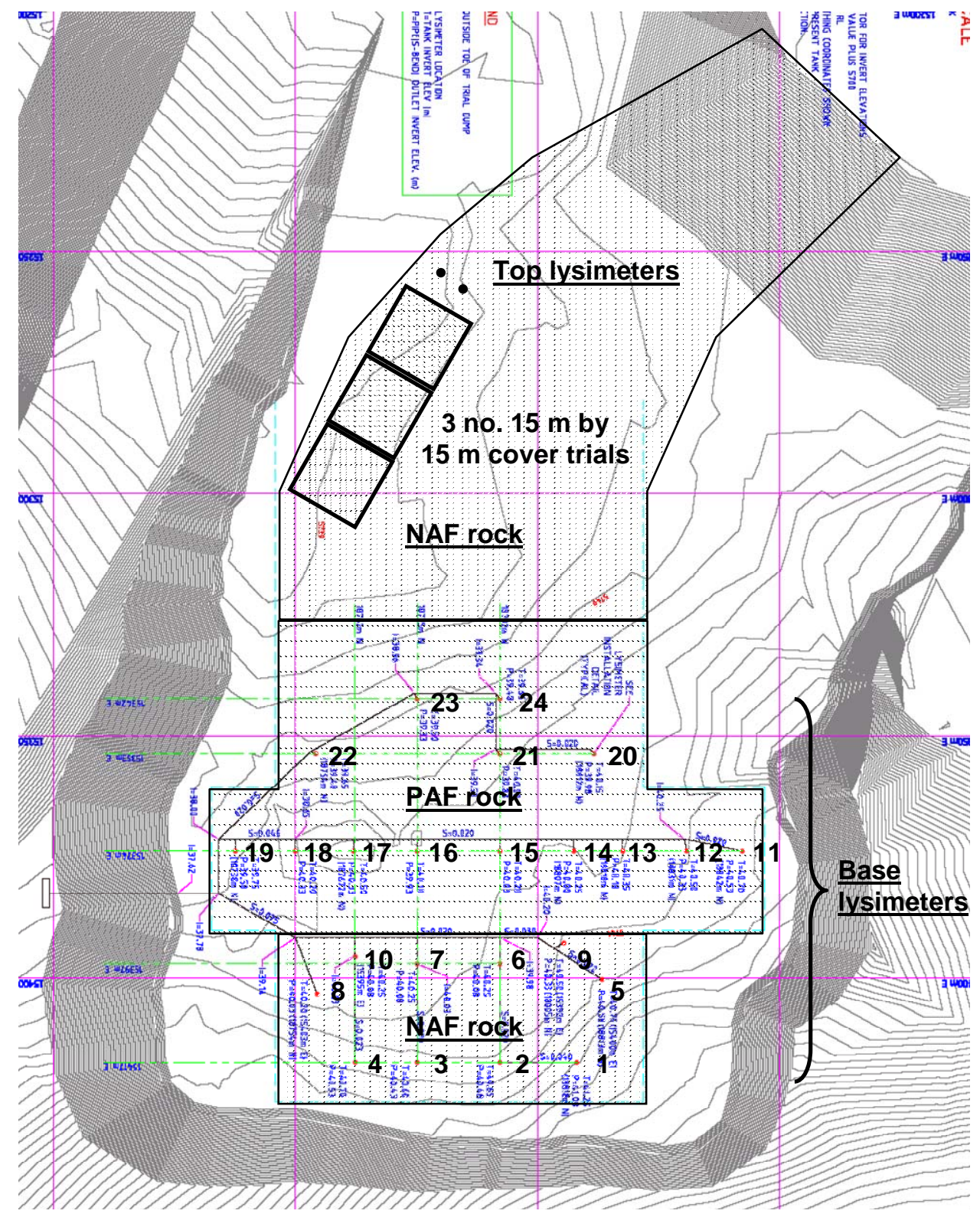

Figure 1 Plan of Cadia's trial rock dump and lysimeter locations

\subsubsection{Base lysimeters}

The 24 base lysimeters were constructed in the base platform for the trial rock dump, distributed over the footprint of the future trial rock dump to intersect seepage beneath its top and sides. The lysimeters comprised open-topped HDPE water tanks measuring $2.4 \mathrm{~m}$ in diameter by $1 \mathrm{~m}$ in height. They were located in holes dug to a depth of about $0.6 \mathrm{~m}$ into the base platform using a tracked excavator. The excavated rock was stockpiled for later backfilling around the lysimeters, with the excess rock removed. A uniform, coarsegrained aggregate termed "crusher dust", having a maximum particle size of approximately $10 \mathrm{~mm}$, was placed to a depth of about $100 \mathrm{~mm}$ in the base of each lysimeter hole to act as bedding for the lysimeter tank 
and to slope the base at $0.5 \%$ towards the lysimeter outlet, leaving a hole about $0.5 \mathrm{~m}$ deep. Once installed, the lysimeters protruded about $0.5 \mathrm{~m}$ above the surface of the base platform. This ensured that no sub-lateral flow across the base platform could enter the lysimeters.

The base lysimeters contain a three-stage filtration system, designed to satisfy the empirical filter design criteria given in Cedergren (1977). The lysimeter outlet was covered by a $100 \mathrm{~mm}$ high geotextile sock filled with screened filtration sand, the base of the lysimeter was filled with screened filter sand to a height just in excess of $100 \mathrm{~mm}$, covering the filter sock, and $100 \mathrm{~mm}$ of screened gravel was placed over that. The remainder of the lysimeter was backfilled with coarse gravel comprising crushed NAF rock. This material was placed over and around the base lysimeters to a height and lateral extent of 2 to $3 \mathrm{~m}$ to protect the lysimeters during subsequent end-dumping of the trial rock dump material. The air-entry value (capillary rise) of this material would be at least equal to the very low air-entry value of the surrounding coarsergrained rock so as to not create a capillary barrier to downward flow.

\subsubsection{Surface lysimeters}

The two surface lysimeters were constructed in the traffic-compacted top surface of the trial rock dump. The lysimeters comprised open-topped HDPE water tanks measuring $2.4 \mathrm{~m}$ in diameter by $2.3 \mathrm{~m}$ in height. They were located in holes dug to a depth of about $2.4 \mathrm{~m}$ into the top surface using a tracked excavator. The rock excavated was stockpiled for later use in backfilling around and within the lysimeters, with the excess rock removed. Crusher dust was placed to a depth of about $100 \mathrm{~mm}$ in the base of each lysimeter hole to act as bedding for the lysimeter tank and to slope the base at $0.5 \%$ towards the lysimeter outlet, leaving a hole about $2.3 \mathrm{~m}$ deep, so that the lysimeters could be installed with their tops flush with the surface. Surface runoff was directed away from the lysimeters.

The surface lysimeters contain a three-stage filtration system, designed to satisfy the empirical filter design criteria given in Cedergren (1977). The lysimeter outlet was covered by a $100 \mathrm{~mm}$ high geotextile sock filled with screened filtration sand, the base of the lysimeter was filled with screened filter sand to a height just in excess of $100 \mathrm{~mm}$, covering the filter sock, and $200 \mathrm{~mm}$ of screened gravel was placed over that. The remainder of the lysimeter and the surrounding holes were then backfilled to approximate the stratigraphy and density of undisturbed traffic-compacted top surface of the trial rock dump. Density was monitored using neutron probe density testing. Replication of in situ conditions within and around the lysimeters is imperative for ensuring that the measured surface fluxes are representative of the actual fluxes (Bews et al., 1997; O'Kane and Barbour, 2003).

\subsubsection{Lysimeter monitoring}

Each lysimeter gravity drains to an individual automated rain-gauge tipping bucket, controlled by a single Campbell Scientific CR10x data logger. The data logger also records data from the weather station, and can be interrogated remotely via telemetry.

\subsection{Measured rainfall, infiltration and seepage}

\subsubsection{Rainfall}

The trial rock dump at Cadia Hill Gold mine is continuously monitored for rainfall, air temperature, relative humidity, solar radiation, and wind speed and direction. Figures 2 and 3 show the daily and cumulative rainfalls over 16 months of monitoring to 1 May 2007. The single largest rainfall event occurred on 18 October 2006, with $73.8 \mathrm{~mm}$ recorded in 24 hours. The greatest frequency of moderate rainfall events $(>10 \mathrm{~mm})$ occurred between June and October 2006. There were 160 days of recorded rainfall and 327 days of no recorded rainfall. The cumulative 16-month rainfall was about $900 \mathrm{~mm}$.

The 30-year average rainfall data for the Australian Bureau of Meteorology (\#063254) weather station located nearest to Cadia at the Orange Agricultural Institute (NSW), show that all but four average monthly rainfall totals exceed those recorded at the trial rock dump over the 16-month monitoring period. The largest shortfalls occurred between March and May 2006 and between November 2006 and May 2007. The cumulative 16 -month rainfall is about $72 \%$ of the 30 -year cumulative average for the 16 -month period to 1 May 2007. 


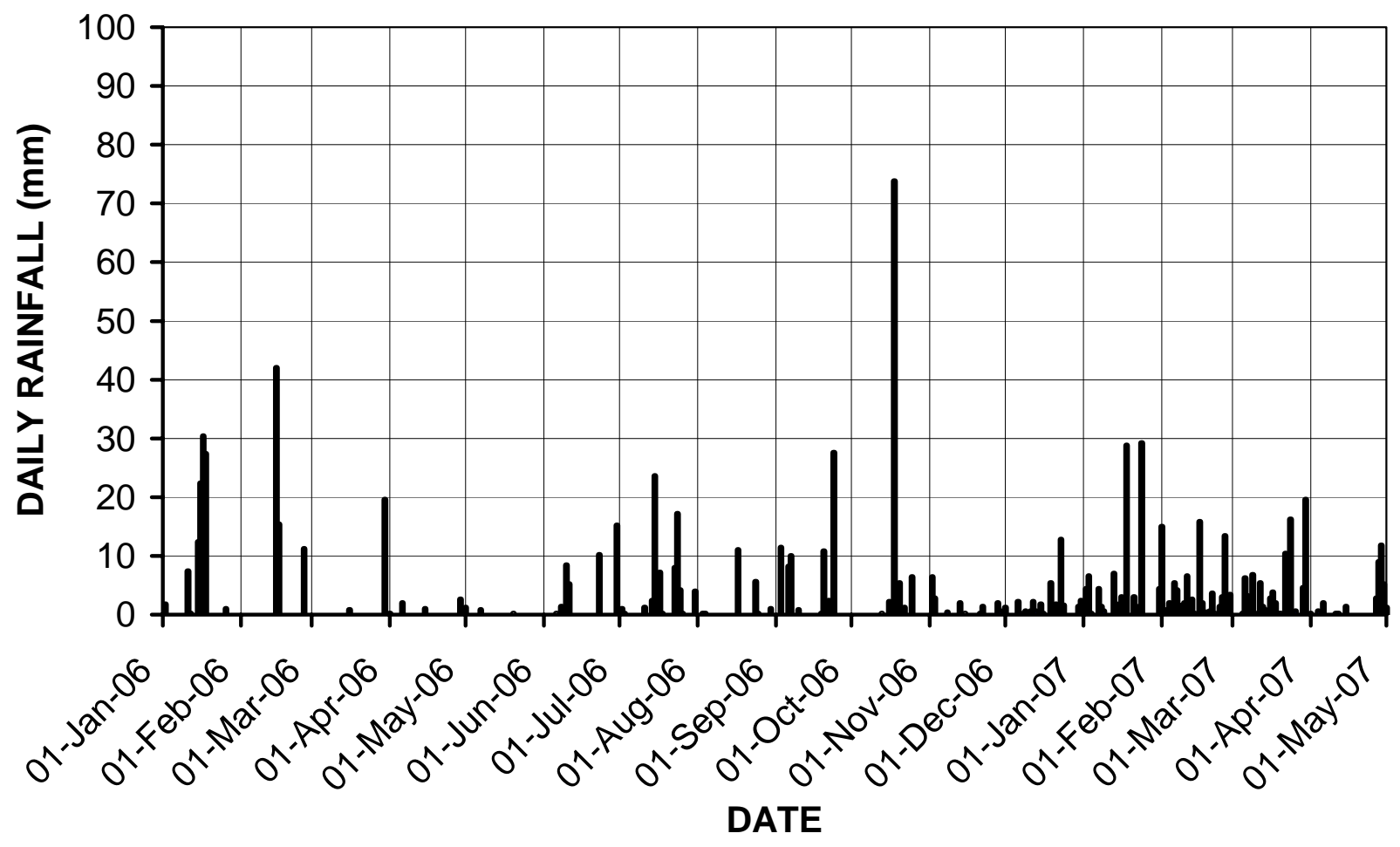

Figure 2 Daily rainfall at Cadia's trial rock dump

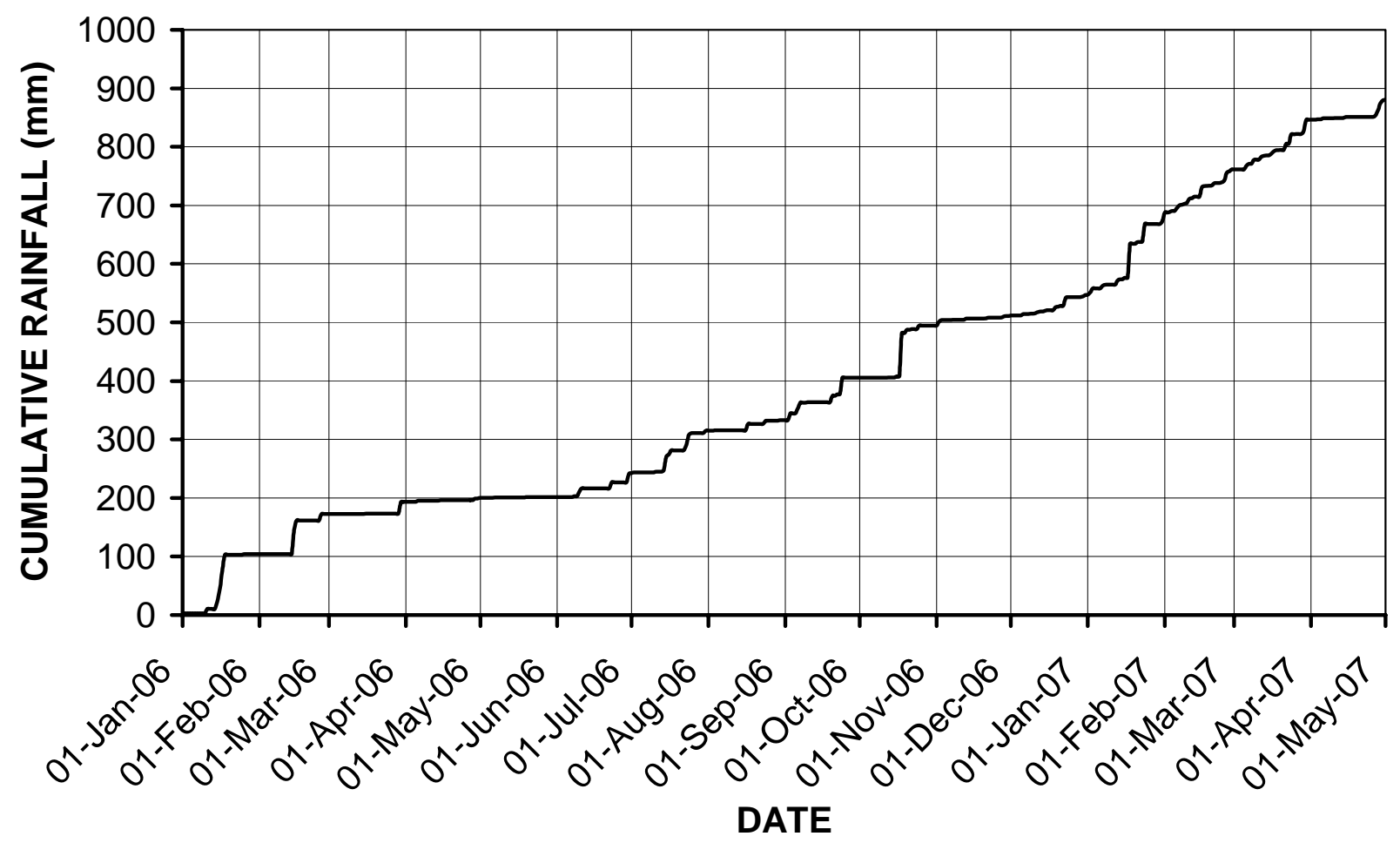

Figure 3 Cumulative rainfall at Cadia's trial rock dump 


\subsubsection{Top surface infiltration}

Surface infiltration into the flat top of the trial rock dump was monitored from 1 July 2006 onwards, following the construction of the dump and the installation of the two lysimeters on its traffic-compacted top surface. The lysimeters responded within 24 hours, building up to an average peak infiltration of $86 \%$ of cumulative rainfall in mid-August 2006, followed by a gradual decline since, with no further infiltration recorded during the relatively dry period from December 2006. Hard-panning of the surface of the dump and the concentration of infiltration at sink holes not intersected by the surface lysimeters may be factors in the loss of recorded infiltration. The patterns of infiltration vary markedly across the dump and with variations in rainfall over time. The average infiltration over the 16-month monitoring period was $445 \mathrm{~mm}$ or about $50 \%$ of the cumulative rainfall of $900 \mathrm{~mm}$, likely reduced by the lower than average rainfall. This is equivalent to an average (unsaturated) hydraulic conductivity for the dump surface as a whole of $1.1 \times 10^{-8} \mathrm{~m} / \mathrm{s}$.

\subsubsection{Base seepage}

When base seepage has been recorded, lysimeters beneath the flat top of the trial rock dump have flowed for about twice as long (40 to 120 days, implying an average hydraulic conductivity during drain-down of $4.3 \times 10^{-6}$ to $1.4 \times 10^{-6} \mathrm{~m} / \mathrm{s}$ ) as those beneath the angle of repose slopes (20 to 60 days, implying an average hydraulic conductivity during drain-down of $8.7 \times 10^{-6}$ to $2.9 \times 10^{-6} \mathrm{~m} / \mathrm{s}$ ), due to the greater height of rock involved.

A greater volume of base seepage has occurred beneath the angle of repose slopes of the dump (30 mm cumulative to 1 May 2007) compared with that beneath the flat top (20 mm cumulative to 1 May 2007), due to the reduced storage capacity of the lower height of rock.

The 14 base lysimeters located beneath the flat top of the trial rock dump have all recorded seepage. They first recorded seepage between about 30 days and 175 days after the completion of the trial rock dump. The cumulative flows to 1 May 2007 have varied over five orders of magnitude, from 0.001 to $175 \mathrm{~mm}$. Expressed as a percentage of cumulative rainfall, the flows have shown a generally diminishing trend with time, recording between $0.0001 \%$ and $20 \%$ of cumulative rainfall to 1 May 2007 , reflecting the drying conditions. The maximum cumulative flow is about $2.8 \%$ of cumulative rainfall, sustained from late March to early June 2006 and approached from mid-April 2007, with a value of $2.5 \%$ of cumulative rainfall to 1 May 2007. The majority of rainfall infiltration (94\% to 1 May 2007) went into storage within the dump.

All but one of the base lysimeters located beneath the angle of repose slopes of the trial rock dump have recorded seepage. The responding lysimeters first recorded seepage between about 30 days and 195 days after the completion of the trial rock dump. The cumulative flows to 1 May 2007 have varied over four orders of magnitude, from 0.0003 to $85 \mathrm{~mm}$. Expressed as a percentage of cumulative rainfall, the flows have shown a generally diminishing trend with time, recording between $0.0003 \%$ and $9 \%$ of cumulative rainfall to 1 May 2007, reflecting the drying conditions. The maximum cumulative flow is about $5.5 \%$ of cumulative rainfall, sustained from 1 August to mid-October 2006, with a value of 3.2\% of cumulative rainfall to 1 May 2007. Again, the majority of rainfall infiltration (93\% to 1 May 2007) went into storage within the dump. The base lysimeters located beneath the angle of repose slopes of the dump have responded more frequently than those beneath the flat dump top.

The observed base seepage occurred under a range of conditions:

- High intensity and low cumulative rainfall (February 2006).

- Low intensity and low cumulative rainfall (May 2006 to July 2006).

- Low and medium intensity with moderate cumulative rainfall (August 2006 to December 2006).

- Low intensity and high cumulative rainfall (January 2007 to February 2007).

The base lysimeter data suggest that there is a relationship between rainfall intensity, the available water storage capacity of the trial rock dump (expressed as a percentage of cumulative rainfall), and the lysimeter response time and flow, following rainfall events. As the trial rock dump wets-up over time and the available storage capacity is depleted, the size of the triggering rainfall event and the response time before base seepage occurs both reduce exponentially. 
At $100 \mathrm{~mm}$ cumulative rainfall, the rainfall event required to trigger base seepage beneath both the flat top and angle of repose slopes of the trial rock dump was of the order of $30 \mathrm{~mm}$ and base seepage occurred within about 10 days. At 10 days, the equivalent hydraulic conductivity for the preferred pathways is $1.7 \times 10^{-5} \mathrm{~m} / \mathrm{s}$ beneath the flat top of the dump and $8.7 \times 10^{-6} \mathrm{~m} / \mathrm{s}$ beneath the angle of repose slopes. Beyond $400 \mathrm{~mm}$ cumulative rainfall, a rainfall event of $5 \mathrm{~mm}$ or less is sufficient to trigger base seepage, and base seepage occurs within 5 days, dropping to 2.5 days at $730 \mathrm{~mm}$ cumulative rainfall. At 2.5 days, the equivalent hydraulic conductivity for the preferred pathways is $4.4 \times 10^{-4} \mathrm{~m} / \mathrm{s}$ beneath the flat top of the dump and $2.2 \times 10^{-4} \mathrm{~m} / \mathrm{s}$ beneath the angle of repose slopes.

The average base seepages due to a triggering rainfall event for base lysimeters located beneath the flat top and angle of repose slopes are, respectively, $12.5 \mathrm{~mm} / \mathrm{event}$ and $8.5 \mathrm{~mm} / \mathrm{event}$.

\subsubsection{Cumulative water balance}

The cumulative water balance for the trial rock dump during the 16-month monitoring period to 1 May 2007 is summarised in Table 1. The average initial and final moisture states calculated for the trial rock dump as a whole over the 16-month monitoring period to 1 May 2007 are summarised in Table 2. Full saturation of the full $15 \mathrm{~m}$ height of the trial rock dump would require an additional $2.872 \mathrm{~m}$ of net infiltration, corresponding to about 6 years of long-term average annual rainfall $(940 \mathrm{~mm})$ or about 9 years of the current reduced annual rainfall $(650 \mathrm{~mm})$, assuming net infiltration of $50 \%$ of annual rainfall. However, the dump would drain rapidly long before it became fully saturated. At about $60 \%$ saturated (Williams and Rohde, 2007), the dump would drain sufficiently rapidly to pass all rainfall infiltration, and this would be expected to occur after about another 2 years of average annual rainfall or about another 3 years of the current reduced annual rainfall.

Table 1 Cumulative water balance for trial rock dump

\begin{tabular}{lcc}
\hline Input & Output & \% of rainfall to 1 May 2007 \\
\hline Rainfall & Infiltration & 49.5 \\
(900 mm to 1 May 2007) & Storage beneath flat top & 47.6 \\
& Storage beneath slopes & 45.6 \\
& Seepage beneath flat top & 1.9 \\
& Seepage beneath slopes & 3.9 \\
& Evaporation & 50.5 \\
\hline
\end{tabular}

Table 2 Initial and final moisture states of trial rock dump

\begin{tabular}{lccc}
\hline Parameter & Initial Value & \multicolumn{2}{c}{ Final Values } \\
& & Beneath flat top & Beneath slopes \\
\hline Volumetric water content & 0.11 & 0.139 & 0.165 \\
Gravimetric moisture content (\%) & 6.2 & 7.9 & 9.4 \\
Degree of saturation (\%) & 33 & 42 & 50 \\
\hline
\end{tabular}

\section{Worldwide data on rock dump infiltration and seepage}

The limited available worldwide data on rock dump infiltration and seepage are summarised in Table 3. For the available data, there is no correlation between rainfall infiltration or base seepage and the thickness or age of the rock dump. However, it might be expected that base seepage, which is the parameter that potentially impacts the environment, would be less than rainfall infiltration, with greater convergence for 
thin lifts of rock and older rock dumps. This is borne out by Figure 4, which shows infiltration or seepage as a percentage of average annual rainfall versus the ratio of rock dump thickness to age in $\mathrm{m} /$ year. Note that the infiltration ranges from 39 to $100 \%$ of average annual rainfall (the higher values corresponding to thin trial rock dumps, with an average 55\% for full-scale rock dumps of various ages and in a range of climates), and the base seepage ranges from 2 to $85 \%$ of average annual rainfall (averaging $37 \%$ for older, full-scale rock dumps in a range of climates). The reported infiltration rates are higher than those commonly assumed for rock dumps, which range from 30 to $60 \%$. Similarly, the reported seepage rates are much higher than is commonly assumed in rock dump design, if seepage is considered.

Table 3 Worldwide data on rock dump infiltration and seepage

\begin{tabular}{|c|c|c|c|c|c|c|}
\hline Location & $\begin{array}{l}\text { Av. Rain } \\
\text { (mm/year) }\end{array}$ & $\begin{array}{c}\text { Age } \\
\text { (years) }\end{array}$ & $\begin{array}{l}\text { Thickness } \\
\text { (m) }\end{array}$ & $\begin{array}{l}\text { Infiltration } \\
\text { (\% av. rain) }\end{array}$ & $\begin{array}{c}\text { Seepage } \\
\text { (\% av. rain) }\end{array}$ & Source \\
\hline \multicolumn{7}{|l|}{ Australia: } \\
\hline Argyle, WA & 700 & 20 & $\sim 50$ & 60 & 60 & Wright (2006) \\
\hline $\begin{array}{l}\text { Cadia, NSW, } \\
\text { trial }\end{array}$ & 938 & 1.33 & 15 & 50 & 1.9 (top) & Herein \\
\hline $\begin{array}{l}\text { Century, } \\
\text { QLD }\end{array}$ & 400 & 8 & 50 & $\sim 60$ & $\sim 2$ & Williams (2007) \\
\hline $\begin{array}{l}\text { Kidston, } \\
\text { QLD }\end{array}$ & 550 & 18 & Av. 40 & $\sim 50$ & $\sim 50$ & Williams et al. (2006) \\
\hline \multicolumn{7}{|l|}{ USA: } \\
\hline Questa, NM & 226 & 39 & 30 to 60 & 50 & - & $\begin{array}{l}\text { McLemore et al. (2006) } \\
\text { Wilson (2007) }\end{array}$ \\
\hline \multicolumn{7}{|l|}{ Canada: } \\
\hline $\begin{array}{l}\text { Whistle, ON, } \\
\text { trial }\end{array}$ & 900 & 3 to 4 & 6.1 & 56 to 58 & 56 to 58 & $\begin{array}{l}\text { Adu-Wusu and Yanful } \\
\text { (2006 and 2007) }\end{array}$ \\
\hline \multirow[t]{3}{*}{$\begin{array}{l}\text { Northern SA, } \\
\text { trials }\end{array}$} & 455 & 3 & $\begin{array}{c}5, \text { loose } \\
5, \text { compact }\end{array}$ & $\begin{array}{c}100 \\
85\end{array}$ & $\begin{array}{l}54 \\
14\end{array}$ & Marcoline et al. (2003) \\
\hline & & 7 & 5 , loose & 100 & 57 & $\begin{array}{l}\text { Nichol et al. (2005) } \\
\text { Wilson (2007) }\end{array}$ \\
\hline & & 0.42 & Trafficked & 39 & - & Carey et al. (2005) \\
\hline \multicolumn{7}{|l|}{$\underline{\text { South America: }}$} \\
\hline Peru, trial & 13 & 0.33 & 10 & 85 & 85 & $\begin{array}{l}\text { Pers. comm., Wilson } \\
(2007)\end{array}$ \\
\hline
\end{tabular}

\section{Conclusions}

The paper presents in some detail the design, construction and monitoring of an instrumented trial rock dump constructed at Cadia Hill Gold mine in New South Wales, Australia to monitor rainfall infiltration and base seepage, plus the limited worldwide data on rock dump infiltration and seepage. The Cadia trial rock dump is on a scale comparable to a conventional rock dump lift, and has demonstrated the following key points:

- The cumulative 16 -month rainfall was about $900 \mathrm{~mm}$, which is about $72 \%$ of the 30 -year cumulative average for the 16-month period to 1 May 2007. 


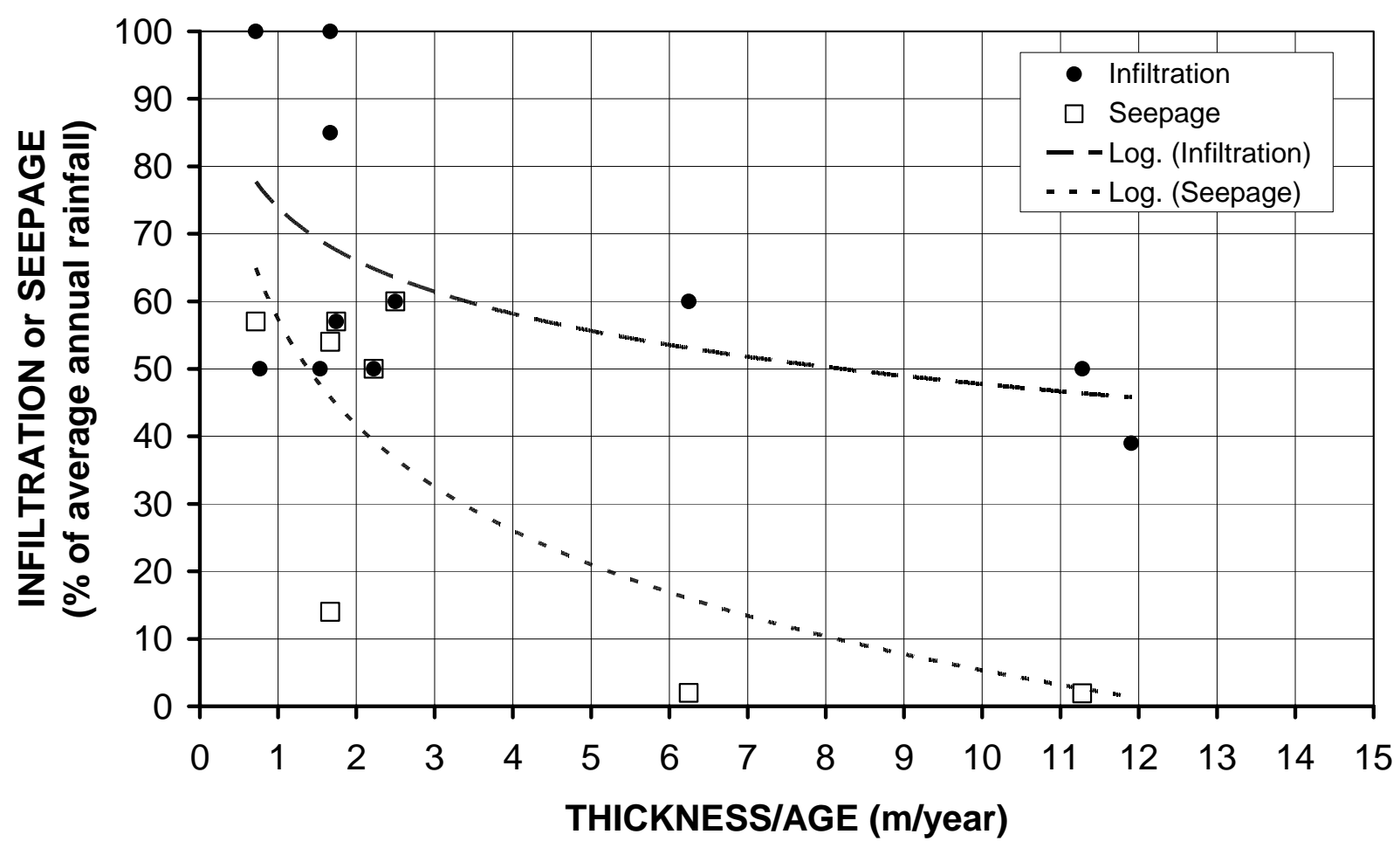

Figure 4 Infiltration and seepage versus rock dump thickness/age

- Surface infiltration into the trial rock dump peaked at $86 \%$ of cumulative rainfall in mid-August 2006 , followed by a gradual decline with declining rainfall, with a recorded infiltration over the 16 -month monitoring period of $445 \mathrm{~mm}$ or about $50 \%$ of the cumulative rainfall of $900 \mathrm{~mm}$, likely reduced by the lower than average rainfall, equivalent to an average (unsaturated) hydraulic conductivity for the dump surface as a whole of $1.1 \times 10^{-8} \mathrm{~m} / \mathrm{s}$.

- The patterns of infiltration and base seepage vary markedly across the trial rock dump and with variations in rainfall over time, likely affected by the relatively dry period from December 2006, hard-panning of the surface of the dump, and the concentration of infiltration at sink holes not intersected by the surface lysimeters and of seepage along preferred pathways.

- When base seepage has been recorded, lysimeters beneath the flat top of the trial rock dump have flowed for about twice as long (40 to 120 days, implying an average hydraulic conductivity during drain-down of $4.3 \times 10^{-6}$ to $1.4 \times 10^{-6} \mathrm{~m} / \mathrm{s}$ ) as those beneath the angle of repose slopes (20 to 60 days, implying an average hydraulic conductivity during drain-down of $8.7 \times 10^{-6}$ to $2.9 \times 10^{-6} \mathrm{~m} / \mathrm{s}$ ), due to the greater height of rock involved.

- A greater volume of base seepage has occurred beneath the angle of repose slopes of the dump ( $30 \mathrm{~mm}$ cumulative to 1 May 2007) compared with that beneath the flat top ( $20 \mathrm{~mm}$ cumulative to 1 May 2007), due to the reduced storage capacity of the lower height of rock.

- The cumulative base seepage beneath the flat top of the trial rock dump is about $2.5 \%$ of cumulative rainfall to 1 May 2007, dropping from a maximum of $2.8 \%$, with the majority of rainfall infiltration (94\% to 1 May 2007) going into storage within the dump.

- The cumulative base seepage beneath the angle of repose slopes of the trial rock dump is about $3.2 \%$ of cumulative rainfall to 1 May 2007, dropping from a maximum of $5.5 \%$, again with the majority of rainfall infiltration (93\% to 1 May 2007) going into storage within the dump.

- The base lysimeters located beneath the angle of repose slopes of the dump have responded more frequently than those beneath the flat dump top. 
- As the trial rock dump wets-up over time and the available storage capacity is depleted, the size of the triggering rainfall event and the response time before base seepage occurs both reduce exponentially.

- At $100 \mathrm{~mm}$ cumulative rainfall, the rainfall event required to trigger base seepage was of the order of $30 \mathrm{~mm}$ and base seepage occurred within about 10 days (equivalent to a hydraulic conductivity for the preferred pathways of $1.7 \times 10^{-5} \mathrm{~m} / \mathrm{s}$ beneath the flat top and $8.7 \times 10^{-6} \mathrm{~m} / \mathrm{s}$ beneath the angle of repose slopes), while beyond $400 \mathrm{~mm}$ cumulative rainfall, a rainfall event of $5 \mathrm{~mm}$ or less is sufficient to trigger base seepage, and base seepage occurs within 5 days.

- The average base seepages due to a triggering rainfall event for base lysimeters located beneath the flat top and angle of repose slopes are, respectively, $12.5 \mathrm{~mm} /$ event and $8.5 \mathrm{~mm} /$ event.

- At about $60 \%$ saturated, the trial rock dump would drain sufficiently rapidly to pass all rainfall infiltration, and this would be expected to occur after about another 2 years of average annual rainfall or about another 3 years of the current reduced annual rainfall.

- The rainfall infiltration measured for the Cadia trial rock dump at $50 \%$ of cumulative rainfall is of a similar order to the average reported for full-scale rock dumps of various ages and in various climates of $55 \%$, although there is a lack of worldwide data for a range of conditions.

- The base seepage measured for the relatively young Cadia trial rock dump at $2.5 \%$ of cumulative rainfall is at the low end of the range reported for full-scale rock dumps of $2 \%$, but well short of the average for older, full-scale rock dumps of $37 \%$, reflecting that these may have reached continuum breakthrough, although there is a lack of worldwide data for a range of conditions.

It is expected that the Cadia trial rock dump will be monitored for a number of years to confirm the trends recorded to date and to investigate when continuum breakthrough occurs. Data are required from other sites under a range of conditions to improve understanding of rock dump wetting-up and seepage phenomena.

\section{Acknowledgements}

This paper includes research data from Cadia Hill Gold mine. The assistance of the mine site personnel involved, and the research funding provided by the company and the Australian Research Council, is gratefully acknowledged.

\section{References}

Adu-Wusu, C. and Yanful, E.K. (2006) Performance of engineered test covers on acid-generating waste rock at Whistle Mine, Ontario. Canadian Geotechnical Journal, 43, pp. 1-18.

Adu-Wusu, C. and Yanful, E.K. (2007) Post-closure investigation of engineered test covers on acid-generating waste rock at Whistle Mine, Ontario. Canadian Geotechnical Journal, 44, pp. 496-506.

Bews, B.E., O'Kane, M.A., Wilson, G.W., Williams, D.J. and N. Currey, N.A. (1997) The design of a low flux cover system, including lysimeters for acid generating waste in semi-arid environments, Proceedings of the Fourth International Conference on Acid Rock Drainage, Vancouver, 31 May-6 June 1997, pp. 747-762.

Carey, S.K., Barbour, S.L. and Hendry, M.J. (2005) Evaporation from a waste rock surface, Key Lake, Saskatchewan. Canadian Geotechnical Journal, 42, pp. 1189-1199.

Cedergren, H. (1977) Seepage, Drainage, and Flow nets. John Wiley \& Sons, New York.

Herasymuik, G.M., Wilson, G.W., Barbour, S.L. and Smith, T. (1995) The characterization of hydrologic properties and moisture migration pathways of a waste rock dump. Nineteenth Annual British Columbia Mine Reclamation Symposium, Dawson Creek, British Columbia, Canada, pp. 234-244.

Marcoline, J.R., Beckie, R.D., Smith, L. and Nichol, C.F. (2003) Mine waste rock hydrogeology - the effect of surface configuration on internal water flow. Proceedings of Sixth International Conference on Acid Rock Drainage, Cairns, Queensland, Australia, 12-18 July 2003, pp. 911-918.

McLemore, V.T., Donahue, K.M., Phillips, E., Dunbar, N., Walsh, P., Guttierrez, L.A.F., Tachie-Menson, S., Shannon, H.R., Lueth, V.W., Campbell, A.R., Wilson, G.W. and Walker, B.M. (2006) Characterization of Goathill North Mine Rock Pile, Questa Molybdenum Mine, Questa, New Mexico. Proceedings of Seventh International Conference on Acid Rock Drainage, St Louis, Missouri, USA, 26-30 March 2006, pp. 1219-1249.

Nichol, C.F., Smith, L. and Beckie, R.D. (2005) Field-scale experiments of unsaturated flow and solute transport in a heterogeneous porous medium. Water Resources Research, 41, 11 p. 
O'Kane, M. and Barbour, L. (2003) Predicting field performance of lysimeters used to evaluate cover systems for mine waste. Proceedings of Sixth International Conference on Acid Rock Drainage, Cairns, Australia, 14-17 July 2003, pp. 327-339.

Williams, D.J. (2007) Consulting to Century Mine.

Williams, D.J. and Rohde, T.K. (2007) Strategies for reducing seepage from surface waste rock piles during operation and post-closure. Proceedings of Second International Seminar on Mine Closure, Santiago, Chile, 16-19 October 2007, pp. 521-523.

Williams, D.J., Stolberg, D.J. and Currey, N.A. (2006) Long-term performance of Kidston's “store/release" cover system over potentially acid forming waste rock dumps. Proceedings of Seventh International Conference on Acid Rock Drainage, St Louis, Missouri, USA, 26-30 March 2006, pp. 2385-2396.

Wilson, G.W. (2007) Private communication.

Wright, A. (2006) Understanding waste rock dump hydrology is essential for effective closure planning and ARD management. Proceedings of First International Seminar on Mine Closure, Perth, Australia, 13-15 September 2006, Australian Centre for Geomechanics, pp. 417-426. 